\title{
Changing locus of mining
}

\author{
Magnus Ericsson ${ }^{1}$
}

Published online: 14 February 2022

(c) The Author(s), under exclusive licence to Springer-Verlag GmbH Germany, part of Springer Nature 2022

All powerful nations in modern history, and probably also before that, have built their domination on a large and profitable mining sector. Over the past 150 years, a succession of countries has built their strength on mining and metals. See Fig. 1. Europe dominated global metals production in the mid to late nineteenth century. Beginning during the second half of the nineteenth century, the USA gradually expanded its production of steel, copper and other metals and became the leading metals producing country. The Soviet Union chose a different, but nevertheless metals-based, industrialisation strategy exploiting the minerals riches of the Urals and the vast untapped resources of Siberia. After the initial move from Europe to North America, the centre of gravity of mining is shifting south of the equator: mineral production in Latin America, Oceania and Asia has grown consistently. ${ }^{1}$

African mine production increased until a peak was reached in the late 1970s, early 1980s. In the early twentyfirst century emerging economies account for most of the metals mined globally. The period from 1850 coincided with a decline in the traditional Asian economic power houses, India being colonised by Britain and ancient imperial China collapsing. ${ }^{2}$ Historically, both these Asian countries have been important but often overlooked metal producers. The first production of zinc on an industrial scale took place in Rajasthan around 1100 and independently in China 300 years later, in both countries long before Europe. Copper production in China reached a peak around the late eighteenth century at 5000-10,000 t annually. ${ }^{3}$ Already in the seventeenth century, Japan was another important producer

\footnotetext{
${ }^{1}$ Sames Carl-Wolfgang, Anaconda - Berichte aus der Rohstoffwelt, Wirtscahftsverlag Langen-Müller/Herbig München 1986.

${ }^{2}$ Maddison Angus, The world economy - A millennial perspective, OECD Paris 2001.

${ }^{3}$ Golas Peter, Science and civilisation in China Volume 5 Part XIII: Mining, Cambridge University Press 1999.
}

Magnus Ericsson

magnus@gladtjarnen.se

1 Luleå University of Technology, Luleå, Sweden of copper sometimes competing directly with European producers. ${ }^{4}$ In the early twenty-first century, China is back as the largest mining country in the world and also India is an important metal producer. Both countries and in particular China are major users of metals.

This geographical movement is obvious also among our authors. Increasingly, they are based in countries in Asia, Africa and Latin America. We welcome and encourage this trend. The rejuvenation of our Editorial Advisory Board continues. In 2021, we have expanded the Board with the following new members:

\section{Tsuyoshi Adachi, Akita University Japan \\ Elizabeth Ana Bastida, CEPMLP University of Dundee Scotland \\ Ian Lange, Colorado School of Mines USA \\ Pamela Lesser, Arctic Center University of Lapland Fin- land \\ Yusheng Li, China Non-ferrous Metals Industry Associa- tion China}

They are all, and in particular together, strengthening and widening our skills and capacity to deal with all types of papers within our scope. Our supporter since many years, Nobuyuki Masuda, has retired and withdrawn from the Editorial Advisory Board. We thank him for his contributions over the years.

In order to further make our work more effective, we have formed an Executive Editorial Group consisting of Mustafa Kumral, Ian Lange, Anton Löf, Linda Wårell and myself. Linda has asked to step down after a long and successful period as Editor-in-Chief and before that Managing Editor. She will now join both the Editorial Advisory Board and the Executive Editorial Group. You may also have noticed that Mineral Economics is now present on Twitter thanks to Ian Lange's efforts. Follow Mineral Economics on Twitter @ Springer_Min_Ec for the latest news and updates and a reminder when new papers are published.

\footnotetext{
${ }^{4}$ Lynch Martin, Mining in world history, Reaktion Books London 2002.
} 
Fig. 1 Locus of world mining 1850-2030, metals and industrial minerals (percent of value of total world production excluding coal) Source: RMG Consulting (See www.rmgco nsulting.org)

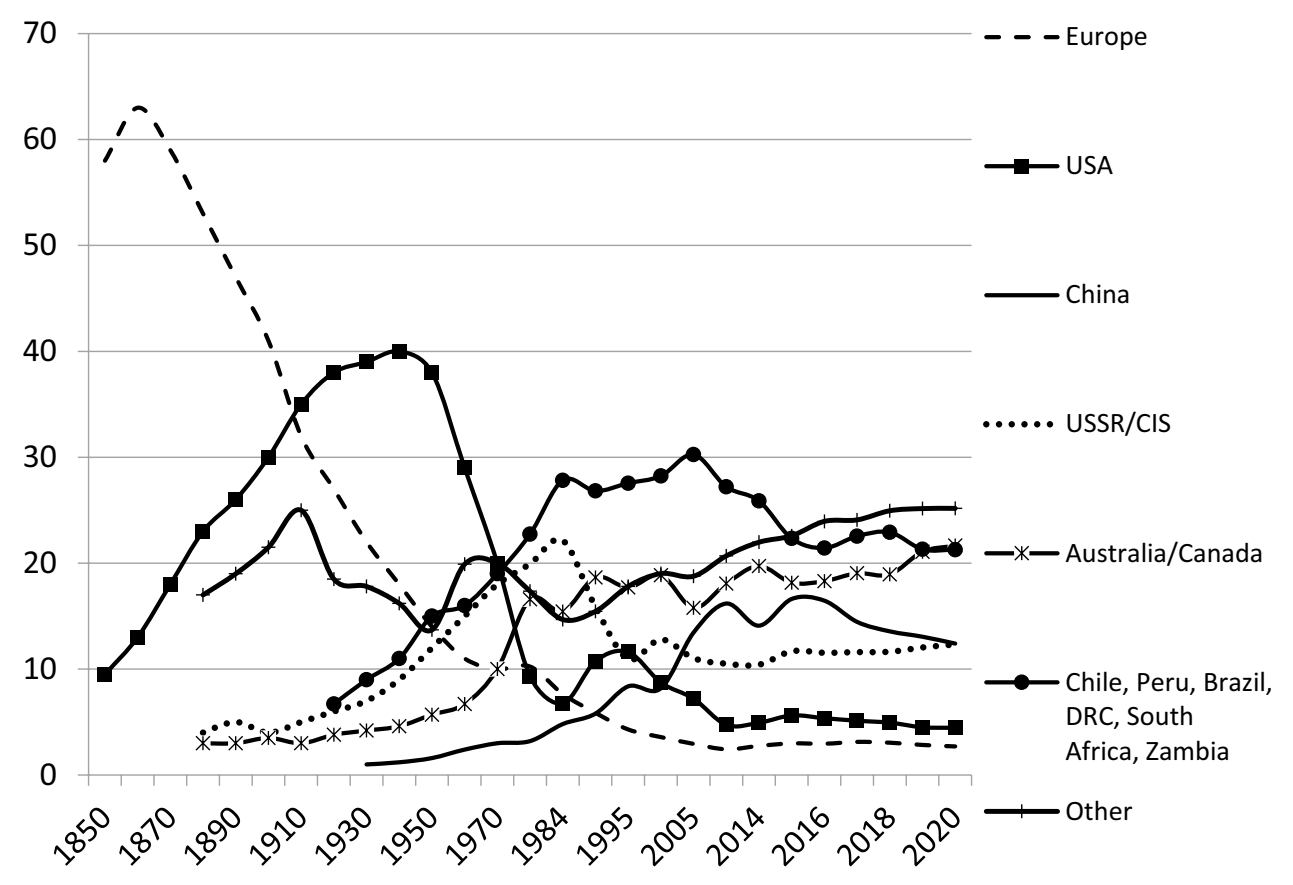

Publisher's Note Springer Nature remains neutral with regard to jurisdictional claims in published maps and institutional affiliations. 